\title{
Photomap of the polythenic chromosomes of Drosophila malerkotliana and in situ mapping of the Hsp83 locus.
}

\author{
Pierre Teodósio Félix $^{1 *}$, José Ferreira dos Santos $^{2}$ \\ 1. Laboratory of Population Genetics and Computational Evolutionary Biology - LaBECom, UNIVISA, Vitória de \\ Santo Antão, Pernambuco, Brazil. \\ *Corresponding author/ Contact: pierrefelix@univisa.edu.br \\ 2. Laboratório de Genética de Microrganismos Departamento de Genética, Universidade Federal de Pernambuco. \\ Av. Morais Rego S/N. Cidade universitária, 50732-970, Recife (PE), Brasil \\ e-mail: recifer@npd.ufpe.br
}

Keywords: Drosophila malerkotliana, Hsp83, Polythenic chromosomes, Photomap, in situ hybridization.

\begin{abstract}
A photomap of the polythenic chromosomes of $D$. malerkotliana was constructed to facilitate the identification of the chromosomal arms and their sections, in order to allow the identification of the breaking points of inversions and the location of the bands marked by in situ hybridization. The photomap included the six chromosome arms corresponding to pairs I (chromosome X), II and III, excluding pair IV and Y chromosome, because they were not visualized in the material examined, probably due to their small size. Through the in situ hybridization technique with the use of a biotined probe of a fragment of the D. melanogaster gene, the Hsp83 locus of $D$. malerkotliana was mapped. The probe hybridized with a frequency of $70 \%$ in section 98 of the IIIR chromosome. This is the first mapped gene in the species, and indicates that possibly the IIIR arm of D. malerkotliana corresponds to the IIIL arm of D. melanogaster, where the Hsp83 gene was located.
\end{abstract}




\section{Introdution}

The mapping of genes by in situ hybridization is an excellent method to establish the homology of the polythenic chromosomes of species close to Drosophila, allowing to clarify their evolutionary relationships. The genes of thermal shock proteins (HSP), due to their high evolutionary conservation, are especially suitable for this approach, as they also allow comparison with other groups of more distant species. The Hsp70 gene of Drosophila melanogaster was used by BONORINO et al (1993) to map the corresponding locus in several species of the willistoni group, demonstrating hybridization in a single section of chromosome III of each species, and confirming the homology of this chromosome with the IIIR arm of D. melanogaster. The homology of the chromosomal arms between the two groups was extended by mapping the genes Hsp83, Hsr, Hsp27 and Ubi (among others) of D. melanogaster in several species of the willistoni group, by RIEGER (1999). Similar studies had already been carried out for the obscura group (SEGARRA et al., 1999) and for the group full (RUIZ et al., 1997) of Drosophila species.

In this work we begin the study of the homology of the chromosomal arms of $D$. malerkoltiana, (subgroup ananassae) with D. melanogaster, (melanogaster subgroup) both of the melanogaster group, by mapping the Hsp83 gene. To facilitate the study it was nescessary to produce a photomap of the main chromosomal arms of $D$. malerkotliana, since the map drawn by JHA and RAHMAN (1973) and reproduced by SORSA (1988), proved to be difficult to compare with the chromosomes of the populations of the species collected in northeastern Brazil.

\section{MATERIAL AND METHODS}

\section{Making the photomap of polythenic chromosomes}

The slides of politenic chromosomes of $D$. malerkotliana of the population of Parque Dois Irmãos (Recife) were prepared by crushing the dissected salivary glands of zero-hour pre pupae, fixed with a solution of acetic acid, water and lactic acid, in a 3:2:1 ratio. The material was stained 
with aceto-lactic orcein (1g of orcein-MERCK, $45 \mathrm{ml}$ of acetic acid, $25 \mathrm{ml}$ of lactic acid $85 \%$, and 30ml of distilled water), according to ASHBURNER (1967). The best slides were photographed under Leica Microscope in increase of 100 X 1.25 with Kodak TMAX Iso 100 film.

\section{In situ hibridization}

For in situ hybridization, the ENGELS et al. (1986) technique was used. After dissection of the larvae, the salivary glands were fixed in $45 \%$ acetic acid and crushed with cover slip in a lactic-acetic solution (lactic acid, water and acetic acid, 1:2:3). The slides were stored at $4^{\circ} \mathrm{C}$ for at least 18 hours. The slides were removed and the slides were submitted to several washes in $2 \mathrm{X}$ SSC and ethanol. The slides were air dried and stored at $4^{\circ} \mathrm{C}$. After these steps, the best slides were selected and only those with intact chromosomes, spread properly, were stored for further hybridization.

For the marking and mapping of the Hsp83 locus in D. malerkoltiana, the clone $\lambda 6$ of the Hsp83 gene of D. melanogaster (HOLMGREN et al., 1981), inserted in the plasmid pBR322, was used as probe. The plasmid was amplified by the transformation of the Xm1 strain of the bacterium Escherichia coli, cultivated in LB medium with ampicillin $\left(100^{\circ} \mathrm{g} / \mathrm{ml}\right)($ SAMBROOK et al., 1989), and was extracted by non-phenolic method (PHILIPPSEN et al., 1991).

To prepare the probe, $1 \mu \mathrm{g}$ of the plasmid containing the gene fragment, marked with biotin by nick-translation with gibco's Bionick kit, was used. The probe marking was tested in "dot blot" with revelation with Estreptavidin - Alkaline Phosphatase (SA-AP), Nitroblue tetrazolium chloride (NBT), 5-bromine-4-chloro-3-indolylphosphate p-Toluidine salt (BCIP). 500ng of probe per blade was used under high astringency conditions (temperature of $36^{\circ} \mathrm{C}$ and $50 \%$ of formamide) for 48 hours. The revelation was performed with SA-AP, NBT and BCIP, followed by the lacto-acetic orcein counter-dye at $0.2 \%$. After drying the blades, the material was permanently assembled with Entellan. 


\section{Results}

The photomap of the polythenic chromosomes of D. malerkotliana was constructed with the six chromosome arms corresponding to pairs I (chromosome X), II and III, which are submetacentric (Figure 1). Pair IV and Y chromosome were not included because they were not visualized in the material examined, probably due to their small size. The photomap is essential to facilitate the identification of the chromosomal arms and their sections, in order to allow the definition of the breaking points of inversions and the location of the bands marked by in situ hybridization. Whenever possible, the sections of the photomap were marked according to the polythenic map drawn by JHA and RAHMAN (1973) for the species, reproduced by SORSA (1988). Additionally, the largest sections were divided into subsections.

In situ hybridization was performed on polythenic chromosome slides of 3 individuals. Fourteen marks were observed in section 98 of the chromosomal arm IIIR (Figure 2), representing $70 \%$ of the markings. Other marks were found in sections 91 (2 marks, 10\%), 87 (2 marks, 10\%) and 85 (1 mark, 5\%) of the same arm and in section 25 (1 mark, 5\%) of the IIL chromosomal arm. 

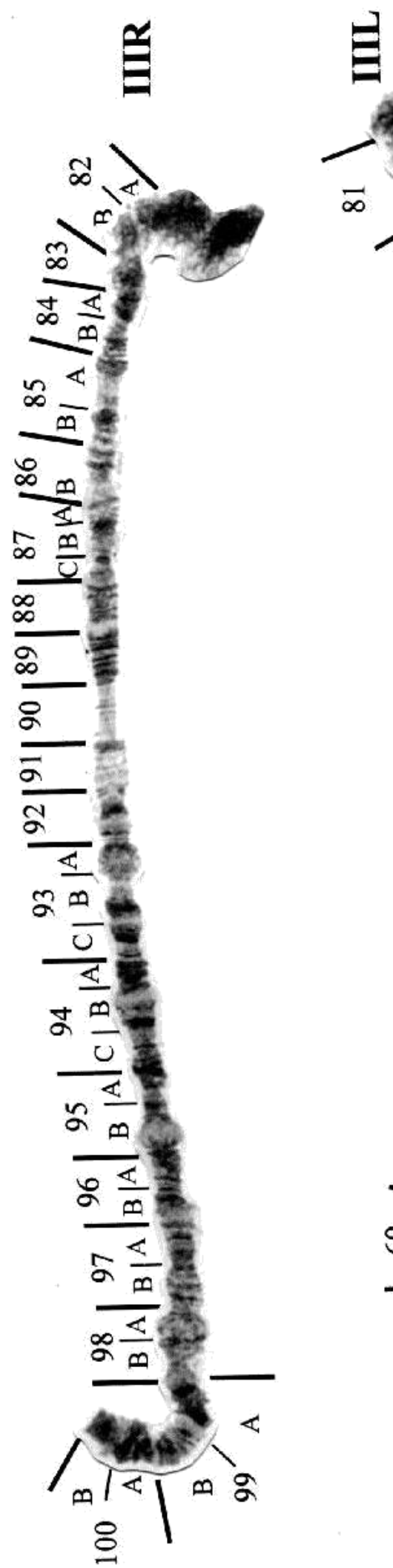

$\infty$

$\infty$

I $\mathrm{m}$

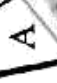

0

$\infty$<smiles>[Mg][TeH]</smiles>
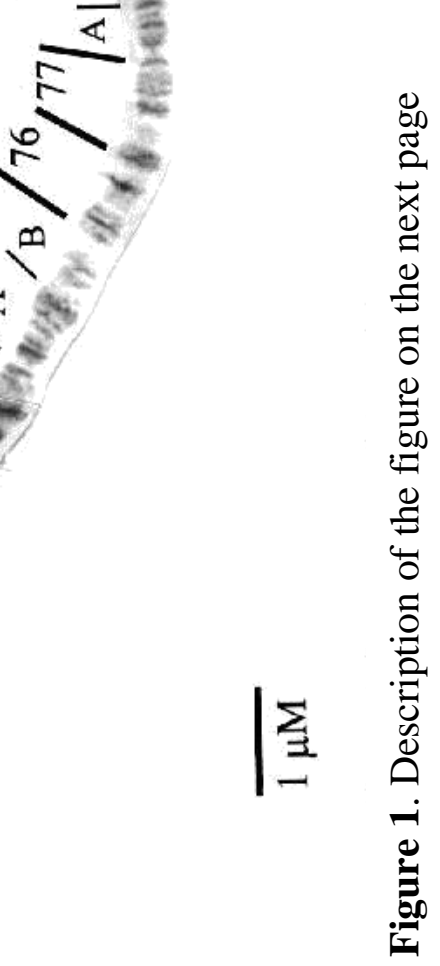

$m$

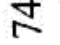

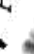

$<$

m

$\measuredangle$

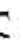

\& $\infty$

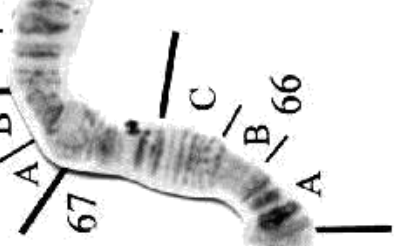

$\mid$\begin{tabular}{l|l|l|}
8 \\
\&
\end{tabular} 


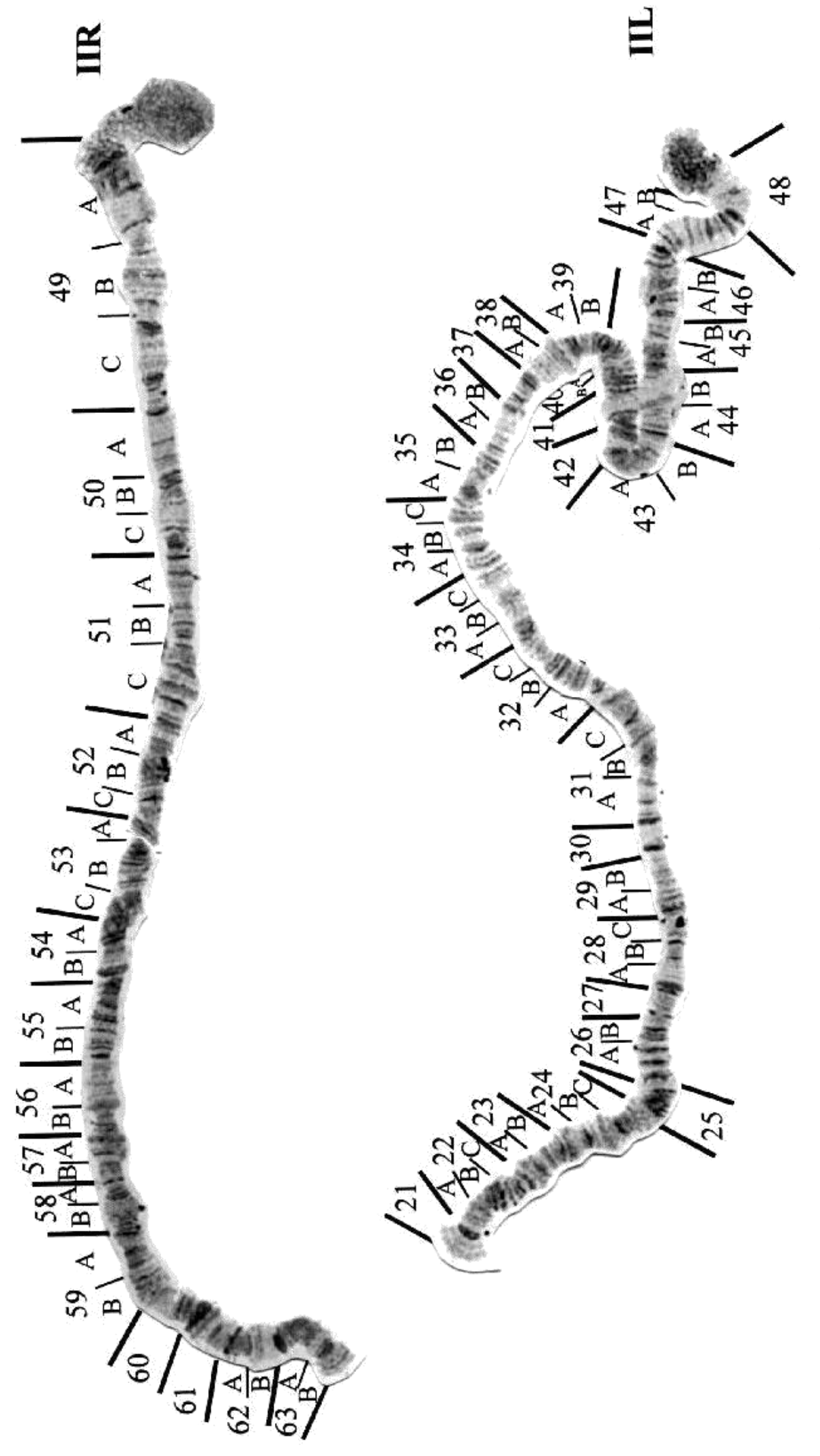



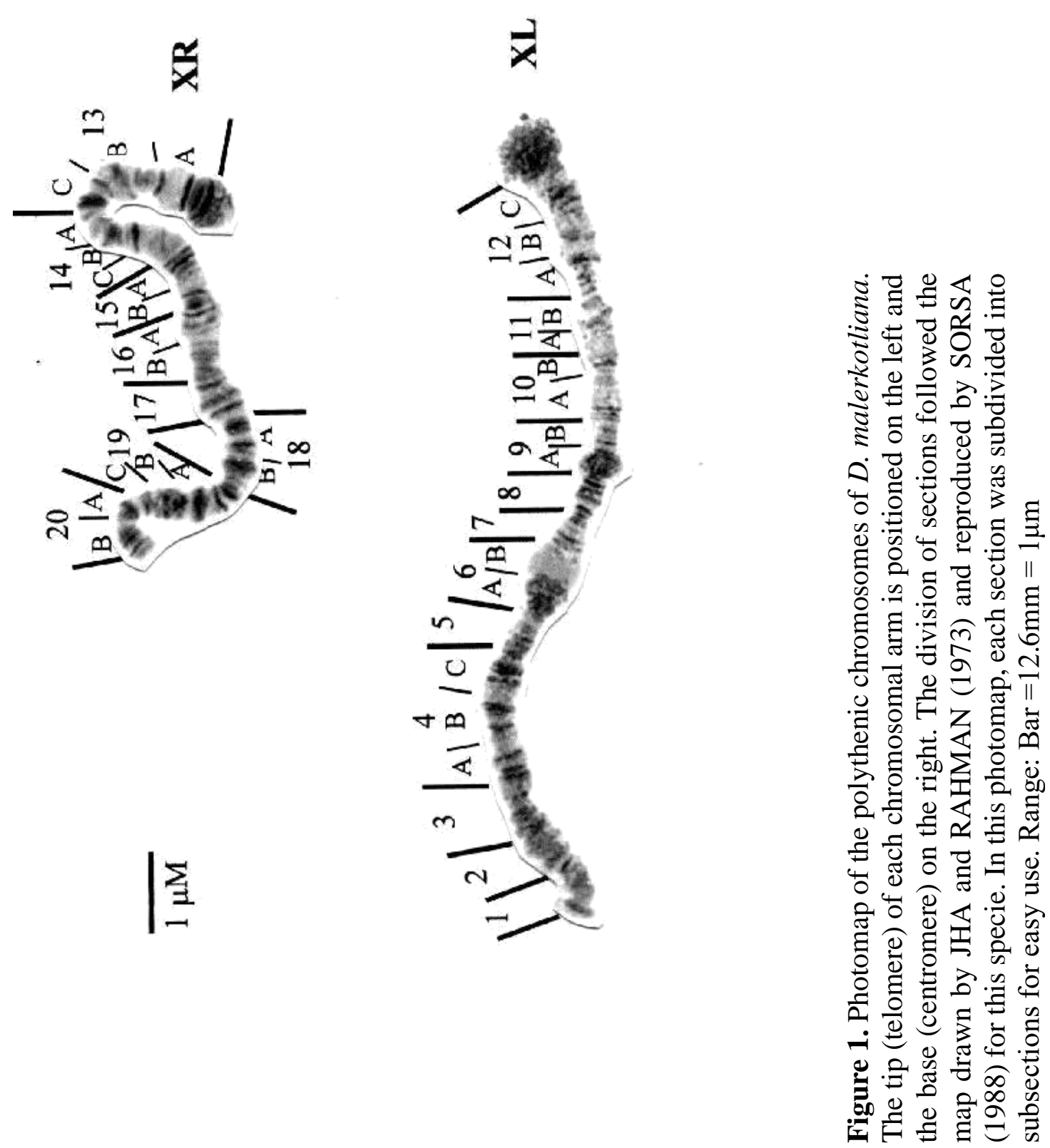
bioRxiv preprint doi: https://doi.org/10.1101/2020.08.05.238600; this version posted August 6, 2020. The copyright holder for this preprint (which was not certified by peer review) is the author/funder, who has granted bioRxiv a license to display the preprint in perpetuity. It is made available under aCC-BY-ND 4.0 International license.

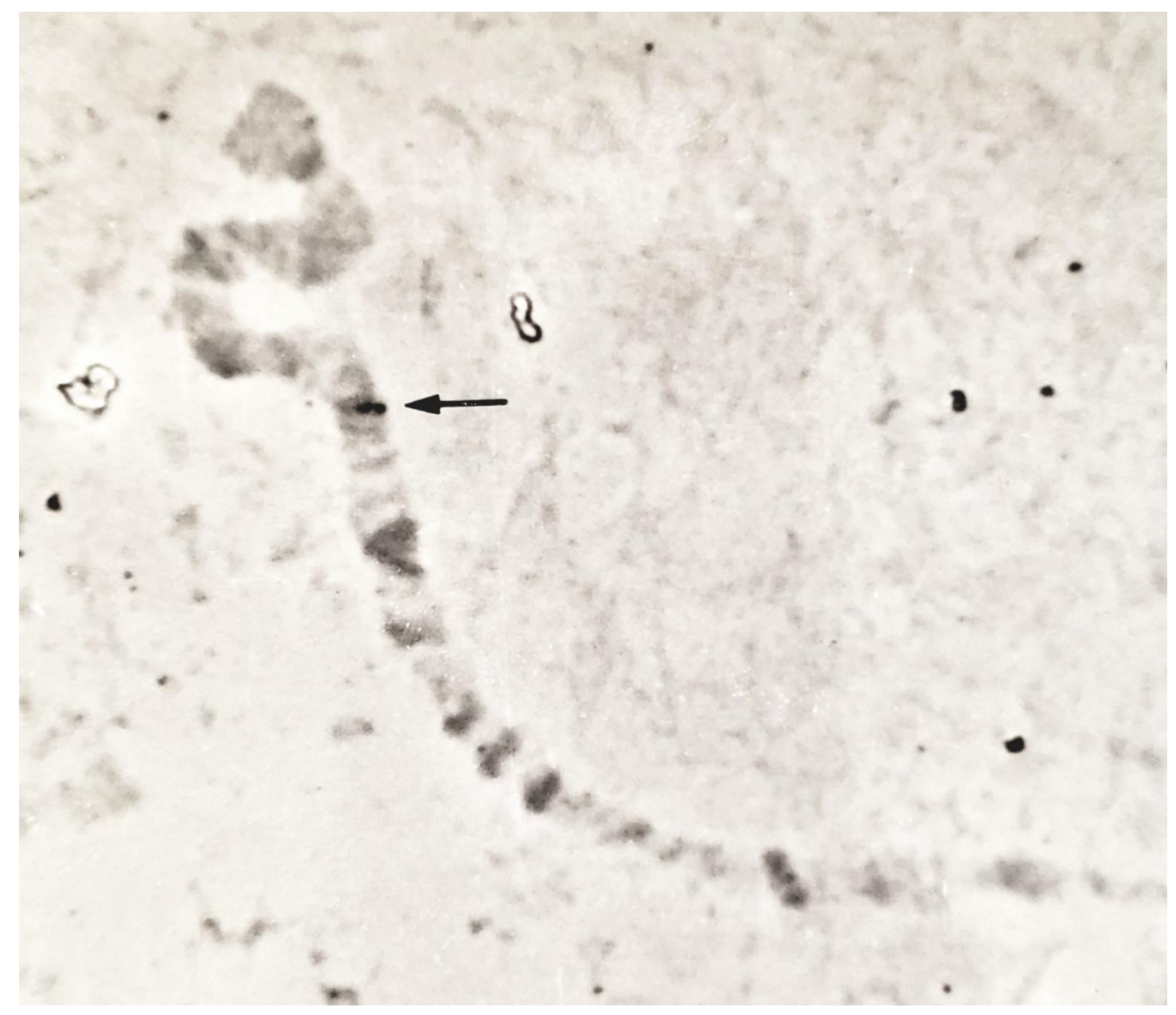

Figure 2. Tip of the chromosomal arm IIIR of D. malerkoltiana, showing the hybridization of the Hsp83 gene probe in section 98. This marking was found in 14 nuclei, representing $70 \%$ of the total markings observed. 


\section{Discussion}

The nuclei of $D$. malerkotliana presented six chromosomal arms, similar to the other species of the ananassae subgroup and different from D. melanogaster, from the melanogaster group, which has five chromosomal arms (LEMEUNIER et al., 1986). The six arms correspond to pairs I (chromosome X), II and III. The PAIR IV and the Y chromosome, although included in the map drawn by JHA and RAHMAN (1973), were not visualized in the analyzed material, possibly due to its small size and its non-polythenization, which is common in several species of Drosophila (SORSA, 1988). The map of JHA and RAHMAN (1973) presents several divergences of bands, inter-bands and "puffs" in relation to the polythenic chromosomes of the populations of the Northeast. This difference is probably related to changes in the chromosomal constitution, resulting from the accumulation of variations over the colonization time, possibly introduced by accumulated inversions and regulatory divergences, due to the large geographical distance from the distribution center of the species.

The Hsp83 gene was mapped in D. malerkoltiana in the section 98 of the chromosomal arm IIIR, with frequency of $70 \%$, being the most consistent mark observed. Whereas in D. melanogaster the Hsp83 gene hybridizes in section 63BD of arm IIIL (ZHIMULEV et al., 1974), this result indicates probable homology of the chromosomal elements IIIR and IIIL between the two species. Additional studies including hybridization of other genes may confirm this homology.

The other hybridization marks, with less consistent results, probably represent other genes of the Hsps family, which present evolutionarily conserved regions (CRAIG et al., 1993). The hypotheses of the presence of pseudogenes or duplication are less likely, as occurs for the Hsp70 locus in D. melanogaster, occupying sections 87A and 87C of the IIIR arm (LIVAK et al., 1978; VAZQUEZ et al., 1993) and for the Hsp83 locus in D. insularis, which has two equally marked regions, one on the XR chromosome (as in any willistoni group) and the other in the IIR that is exclusive to it (RIEGER, 1999). 
In this work, a photomap was made and mapped by in situ hybridization a physiologically important gene, the first being mapped in D. malerkotliana, representing the beginning of a complete study of the chromosomal evolution of the species, which will also include the induction of poufs by stress or hormones such as ecdysone.

\section{References}

Ashburner, M. (1967). Patterns of puffing activity in the salivary gland chromosomes of Drosophila. I. Autosomal puffing patterns in a laboratory stock of D.Melanogaster. Chromosoma, 27: 477-63.

Craig,E. A.; Ga mbil, B. D.; Nelson, R. J. (1993). Heat shock Proteins: molecular chaperones of protein biogenesis. Microbiol. Rev., v. 57, p. 402-414.

Engels, W. R.; Preston, C. R.; Thompson, P.; Eggleston, W. B. (1986). In situ hibridization to Drosophila salivary chromosomes with biotinylated DNA probes and alkaline phosphatase. Focus, v. 8, p. 6 - 8, 1986.

Garbe, J. C.; Pardue, M. L. (1986). Heat shock locus 93D of Drosophila melanogaster: a spliced RNA most strongly conserved in the intron sequence. Proc. Natl. Acad Sci. USA, v. 83, p. 1812 1816.

Holmgren, R.; Corces, V.; Morimoto, R.; Blackman, R; Meselson, M. (1981) Sequence homologies in the 5' regions of four Drosophila heat shock genes. Proc. Natl. Acad. Sci., USA, v. 78 , p. $3775-3778$.

Jha, A. P.; Rahman, S. M. Z. (1973). On crossing between Drosophila bipectinata and Drosophila malerkotliana. Cytologia, 38: p.425-436. 
Jindal, S. (1996). Heat shock proteins: applications in health and disease. Trends Biotech., v. 14, p. $17-20$.

Lemeunier, F.; David, J. R.; Tsacas, L.; Ashburner, M. (1986). The melanogaster species group. In: Ashburner, M., Carson, H.L.; Thompson, Jr. J. N. (Eds), The Genetics and Biology of Drosophila, Academic Press, London.3:147-256.

Lindquist, S.; Craig, E. A. (1988). The heat-shock proteins. Annu. Rev. Genet., v. 22, p. 631677.

Livak, K. J.; Freund, R.; Shweber, M.; Wensink, P. C.; Meselson, M. (1978). Sequence organization and transcription at two heat shock loci in Drosophila. Proc.Natl. Acd. Sci. USA, v. 11, p. $5613-5617$.

Nover, L. (1991). Cell cycling and DNA synthesis. In: NOVER, L. Heat shock response. CRC Press, Boca Raton, p. $363-371$.

Panniers, R. (1994). Translatinal control during heat shock. Biochimie, v. 76, p. 737 -747.

Pardue, M. L.; Ballinger, D. G.; Hogan, N. C. (1992). The heat shock response. Cells coping with transient stress. Annals New York Acad. Sci., v. 663, p. 125 - 138.

Pauli, D.; Arrigo, A.-P.; Tissières, A. (1992). Heat shock response in Drosophila. Experientia, v. 48 , p. $623-628$.

Philippsen, P.; Stotz, A .; Scherf, C. (1991). DNA of Saccharomyces cerevisae. Meth. Enzymol., 194: 169-182. 
Rieger, T. T. (1999). Mapeamento por hibridização in situ e expressão no desenvolvimento de genes de resposta a estresses e ao hormônio ecdisona em espécies do grupo willistoni de Drosophila. Tese de Doutorado. UFRGS. p.138

Ruiz, A.; Ranz, J. M.; Cáceres, M.; Segarra, C.; Navarro, A.; Barbadilla, A. (1997). Chromosomal evolution and comparative gene mapping in the Drosophila repleta species group. Braz. J. Genet., v. 20, p. 553-565.

Sambrook, J.; Fritsch, E. F.; Maniats, T. (1989) Molecular cloning: laboratory manual. 2nd ed. Cold Spring Harbor Laboratory Press, Cold Spring Harbor, 3 Vol.

Segarra, C.; Lozovskaya, E. R.; Ribó, G.; Aguadé, M.; Hartl, D. L. (1995). P1 clones from Drosophila melanogaster as markers to study the chromosomal evolution of Muller 's $A$ element in two species of the obscura group of Drososphila. Chromosoma, v. 104, p. 129-136.

Sorsa, V. (1988). Chromosome maps of Drosophila. Vol.I. CRC Press Inc., Boca Raton. 200 pp.

Vazquez, J.; Pauli, D.; Tissiéres, A. (1993). Transcriptional regulation in Drosophila during heat shock: a nuclear run-on analysis. Chromosoma, v. 102, p. $233-248$.

Welch, W. J. (1993). How cells respond to stress. Scientific American, v. 268, p. 34-41.

Zhimulev, I. F.; Grafodatskaya, V. E. (1974). A simple method of induction of anaerobiosis puffs in Drosophila melanogaster. Dros. Inf. Serv., v .51, p. 96. 


\section{Attachments}

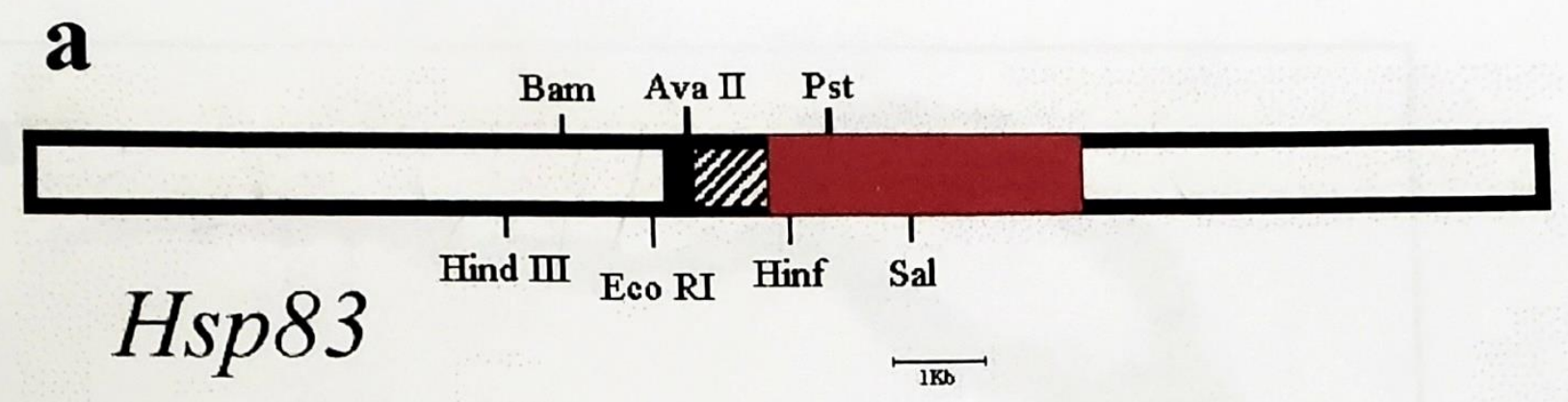

b

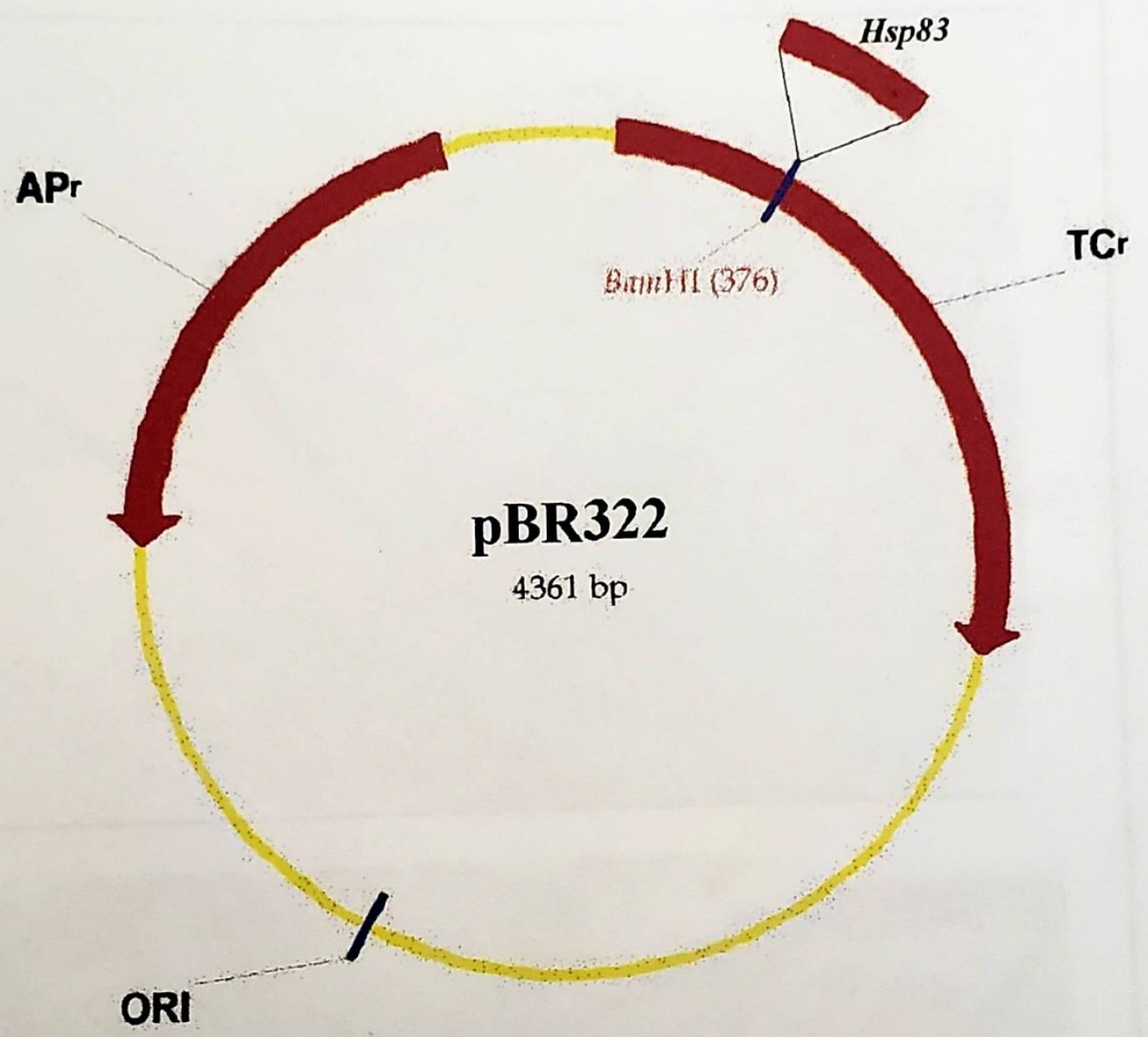

Figure 1. Restriction map of clone $\lambda 6$ with $3.4 \mathrm{~kb}$ (a), containing the fragment of the Hsp83 gene of Drosophila melanogaster inserted in plasmid pBR322 (b) sequence homologies in the 5, regions of four Drosophila heat shock genes (HOLMGREN and Cols., 1981). 